\title{
Effects of Salivary Immune Response to Streptococcus mutans on Caries Occurrence and Caries Development in Mice with Autoimmune Disease
}

\author{
Takahide Maeda, Kazunori Takamori, Masaru Shima and Yoichi Kurihara
}

(Received 28 September and accepted 5 December 1994)

Key words: dental caries, autoimmune disease, mice, salivary immunoglobulin level

\begin{abstract}
MRL/1 strain mice, which possess a lymphoproliferative gene inducing swelling of systemic lymph nodes, develop a SLE (systemic lupus erythematosus)-like syndrome at around $8 \mathrm{w}$ of age. MRL/n mice, which carry $99.6 \%$ of the genes of MRL/l mice, lack the gene for lymphoproliferation and exhibit only a slight degree of lymph node swelling late in life.

This study investigated whether the salivary immune response caused by Streptococcus mutans $(S$. mutans) infection prevented dental caries in MRL/l and MRL/n mice after $8 \mathrm{w}$ of age.

A total of $10 \mathrm{MRL} / 1$ mice and $10 \mathrm{MRL} / \mathrm{n}$ mice were fed a commercial pellet diet without sucrose until $74 \mathrm{~d}$ of age, and then fed Diet 2000 containing $56 \%$ sucrose ad libitum from 75 to $130 \mathrm{~d}$ of age.

On d 75, both strains of mice were inoculated with S. mutans JC-2 for $7 \mathrm{~d}$. At $130 \mathrm{~d}$ of age, saliva samples were collected and caries scores were assessed.

The results obtained suggested that the salivary immune response was one of the most important factors regulating caries occurrence.
\end{abstract}

\section{Introduction}

Michalek and McGhee ${ }^{[1]}$ pointed out that the following factors must be considered when using an animal model in a caries-promotion study: (1) the caries-promoting diet, (2) the cariogenic microorganism, and (3) the susceptible host employed. As an animal model, inbred strains of mice have several advantages over rats in dental research, since genetical control can be maintained well. It is not difficult to induce caries lesions by infection of inbred mice with $S$. mutans serotype $c^{[2]}$. Kurihara et al.$^{[3]}$ demonstrated that the H-2 region is genetically related to susceptibility to dental caries using several kinds of inbred mice with different haplotypes.

Several laboratories have demonstrated that salivary immunoglobulin $\mathrm{A}(\operatorname{Ig} \mathrm{A})$ and serum antibodies are important for preventing dental caries in human and animals ${ }^{[4-6]}$. However, Krasse et al. ${ }^{[7]}$ found no consistent correlation between antibodies and dental caries prevalence among adults.

Murphy et al. ${ }^{[8]}$ produced MRL/Mp-lpr/lpr(MRL/l) mice, which possess a lymphoproliferative (lpr) gene inducing swelling of systemic lymph nodes, and develop a lupus-like syndrome characterized by antibodies against nucleic acids and immune-complex glomerulonephritis. Several studies have indicated that autoimmunity in MRL/lpr mice is caused by proliferation of a distinct subpopulation of $\mathrm{T}$ cells $\mathrm{s}^{[8,9]}$.

These proliferating cells are thought to be helper T cells because they lack Lyt-2 $2^{[9]}$, which is found on suppresser/cytotoxic T cells. However, these T cells support immunoglobulin synthesis by B cells in vitro $^{[10,11]}$. MRL/Mp- +/+ (MRL/n) mice, which carry $99.6 \%$ of the same genes as MRL/l mice and lack the lpr gene, exhibit only a slight degree of lymph node swelling late in life ${ }^{[8]}$. Therefore, for research on the immune response in MRL/l mice, MRL/n mice are thought to provide the best control.

The purpose of our previous study ${ }^{[12]}$ was to examine the relationship between salivary immunoglobu-

前田隆秀、高森一乗、島 優、栗原洋一

Department of Pedodontics, Nihon University School of Dentistry at Matsudo, Matsudo, Chiba 271, Japan

To whom all correspondence should be addressed to: Dr. Takahide Maeda, Department of Pedodontics, Nihon

University School of Dentistry at Matsudo, 2-870-1 Sakaecho-Nishi, Matsudo, Chiba 271, JAPAN 
lin levels and caries development in MRL/l mice using MRL/n mice as a control. Both strains of mice were inoculated with $S$. mutans at $22 \mathrm{~d}$ of age, when no signs of disease were evident, and MRL/l mice were recognized to have massive lymph node enlargement as an autoimmune disease at the time of the caries score assessment. On the other hand, MRL/n mice were healthy throughout the experimental period. The purpose of this study was to determine whether salivary immunoglobulin levels regulated caries occurrence in MRL/l mice, using MRL/n mice as a control. At $75 \mathrm{~d}$ of age of $S$. mutans inoculation, MRL/l mice already suffered from autoimmune disease and their immune function was thought to be defective. MRL/n mice remained healthy throughout the experimental period.

Mice

\section{Materials and methods}

MRL/1 mice and MRL/n mice were obtained from Jackson Laboratory, U.S.A.

All the mice employed were bred in our colony under specific pathogen-free conditions, and were fed on Diet 2000, containing $56 \%$ sucrose, ad libitum and sterilized water during both experimental periods.

\section{Bacterial strains and conditions}

S. mutans strain JC-2 (serotype $c$ ), which is resistant to streptomycin $(1.0 \mathrm{mg} / \mathrm{ml})$, was used. The strain was maintained on brain heart infusion (BHI) agar containing excess calcium carbonate at $4^{\circ} \mathrm{C}$. Bacteria grown to $\log$ phase in $\mathrm{BHI}$ broth for $18 \mathrm{~h}$ at $37^{\circ} \mathrm{C}$ in an atmosphere of $\mathrm{CO}_{2}(5 \%)$ in nitrogen $(95 \%)$ were used.

Prior to the experiments, it was confirned that no S. mutans was present in the flora using oral swabs and culturing on Mitis Salivarius (MS) and BHI agar plates.

\section{Measurement of caries score}

The mandibles were stained with murexide solution, and the molars were hemisectioned. The buccal, lingual, sulcal and proximal molar surfaces were subsequently scored for caries analysis according to the Keyes $^{[13]}$ procedure modified for mice.

\section{Measurement of immunoglobulin levels in saliva}

Salivary levels of IgA against $S$. mutans JC-2 were measured by ELISA using $50 \mu 1 S$. mutans of optical density 1 as the primary antibody, and serial dilutions of the saliva samples were added to the wells. Absorbance was read at $415 \mathrm{~nm}$.

\section{Experimental design}

Ten MRL/l female mice and $10 \mathrm{MRL} / \mathrm{n}$ female mice were used. Until d 74, both inbred strains were fed a pellet diet without sucrose and sterilized water ad libitum. On d 75 they were inoculated with $50 \mu 1$ of S. mutans JC-2 $\left(1 \times 10^{9}\right.$ cells $\left./ \mathrm{ml}\right)$ for $7 \mathrm{~d}$ when MRL/l mice showed massive systemic enlargement of lymph nodes, and MRL/n mice were healthy. After $75 \mathrm{~d}$ of age, all mice were fed on Diet 2000, containing $56 \%$ sucrose, ad libitum and sterilized water until $130 \mathrm{~d}$ of age. Saliva samples from MRL/l and MRL/n mice at $130 \mathrm{~d}$ of age were collected using capillary tubes by subcutaneous injection of pilocarpine $(10 \mathrm{mg} / \mathrm{kg})$ as a stimulant and stored at $-20^{\circ} \mathrm{C}$.

\section{Caries scores}

\section{Results}

The mean caries score and standard error in MRL/l and MRL/n mice were $230.8 \pm 15.6$ and $31.6 \pm$ 11.9 , respectively showing a significant difference $(\mathrm{p}<0.01)$ ( Table 1$)$.

\section{Levels of salivary IgA against $S$. mutans}

The mean levels of salivary $\operatorname{IgA}$ against $S$. mutans in MRL/1 mice were significantly lower than those in MRL/n mice at $130 \mathrm{~d}$ of age after infection with $S$. mutans on d 75 (Table 2). 


\section{Discussion}

Kurihara et al ${ }^{[3]}$ have demonstrated that $\mathrm{H}-2$ (murine Major Histocompatibility Complex) affects susceptibility to dental caries in mice. Meanwhile it has been reported that bacterial adhesion is inhibited by secretory $\operatorname{IgA}^{[14]}$. Several laboratories have shown that salivary IgA is important for preventing dental caries in humans and animals. Some studies have demonstrated the protective effects of salivary $\operatorname{IgA}$, $^{[4,6,15-17]}$ whereas others support serum antibody-mediated control of caries lesions ${ }^{[18,19]}$. Nevertheless, studies in humans have shown that oral immunization with $S$. mutans whole cells results in the induction of a salivary $\operatorname{Ig} \mathrm{A}$ response $\mathrm{e}^{[20,21]}$.

Gregory et al. ${ }^{[22]}$ reported that caries-free subjects or individuals with low caries susceptibility exhibited significantly higher levels of naturally occurring salivary $\operatorname{IgA}$ and serum $\operatorname{IgG}, \operatorname{IgA}, \operatorname{IgM}$ against a $S$. mutans ribosomal preparation than subjects with high caries susceptibility.

Human MHC antigens may regulate the host immune response including the interaction between immunoglobulins and the HLA-DR antigen, since a human MHC class 2 antigen has been demonstrated to associate with helper $\mathrm{T}$ cell activity in the control of dental caries ${ }^{[23]}$. Niiyama et al. ${ }^{[24]}$ reported that the immune response to dental caries was controlled by the class 2 gene(s) in the major histocompatibility complex of the rat (RT1). MRL/l mice develop a T-cell lymphoproliferative syndrome with a systemic lupus erythematosus (SLE)-like disorder, and the female mice develop the disorder earlier than the male mice. The disease is marked by massive lymph node enlargement, hypergammaglobulinemia characterized by antibodies against nucleic acids, and by immune-complex glomerulonephritis. The massive lymph node enlargement is due to abnormal T cells which have abnormal helper and suppressor/cytotoxic function.

In response to the lpr mutant gene, under non-stimulated conditions, Ly 1+T cells develop, causing the polyclonal BCDF, a B-cell differentiation factor, to produce a high level of immunoglobulin and autoimmune antibodies $^{[8]}$. Therefore we investigated how MRL/l mice with polyclonal hyperimmunoglobulins are affected by dental caries development, and compared them with MRL/n mice, which have the same $\mathrm{H}-2$ haplotype and normal serum immunoglobulin levels ${ }^{[12]}$.

In a previous study ${ }^{[1]]}$ the salivary IgA level of MRL/l mice at $115 \mathrm{~d}$ of age inoculated with $S$. mutans was significantly higher than that of MRL/n female mice in the infection group. In particular, serum $\operatorname{IgA}$ levels in MRL/l mice were two to three times higher, and serum IgG levels were five to six times higher than those in MRL/n mice. Similar results for serum immunoglobulin levels were obtained by Murphy et al. ${ }^{[8]}$ and Andrews et al. ${ }^{[25]}$ The salivary IgA levels in the infected MRL/l mice on $\mathrm{d} 22$ were significantly higher than those in the non-infected group at $115 \mathrm{~d}$ of age, although the caries scores of the MRL/l mice were not significantly different from those of MRL/n mice ${ }^{[12]}$. These results suggested no regulation of dental caries development by salivary IgA and serum IgA and IgG in MRL/1 mice. The immune response of MRL/l mice at the time of caries development might be weak, because polyclonal hyperimmunoglobulin levels by autoimmune disease developed around $8 \mathrm{w}$ of age ${ }^{[8]}$, when dental caries had already occurred. The increase in immunoglobulin against $S$. mutans or dental lesions may have been responsible for the higher salivary IgA levels in infected MRL/l mice than those in non-infected MRL/l mice. Lehner et al. ${ }^{[26]}$ reported that serum IgG anti-S. mutans antibodies were negatively correlated with a previous history of caries in humans. Our results indicated that the high salivary immunoglobulin levels in MRL/l mice were not related to dental caries development compared with MRL/n mice. Salivary immunoglobulin may prevent dental caries if high levels are maintained at the incipient stage of cariogenesis.

Accordingly, in this study S. mutans was inoculated on d 75 for $7 \mathrm{~d}$, when the abnormal immune response with hyperimmunoglobulinemia occurred in MRL/l mice, and the immune response was normal in MRL/n mice. The mean caries score on $\mathrm{d} 130$ in MRL/l mice was more than seven times higher than that in MRL/n mice, the difference being significant $(\mathrm{p}<0.01)($ Table 1$)$.

The mean caries score of MRL/n mice which were inoculated with $S$. mutans on $\mathrm{d} 75$ was noticeably decreased compared with that after inoculation at $22 \mathrm{~d}$ of age. The reason for the decline in caries score in $\mathrm{MRL} / \mathrm{n}$ mice was thought to be maturation of enamel calcification with age.

On the other hand, the mean caries score of MRL/l mice which were inoculated with $S$. mutans on $\mathrm{d} 75$ 
was increased in comparison with that on $\mathrm{d} 22$ (Table 1). One of the reasons for the increased caries score was thought to be the poor immunoglobulin response to $S$. mutans antigens at $75 \mathrm{~d}$ of age in MRL/l mice. Wofsy et al. ${ }^{[27]}$ indicated that the proliferating cells in MRL/l mice lack an important functional marker of helper T cells (L3T4), which participates in the response to MHA (major histocompatibility antigen)2, and Lyt-2, which participates in the response to MHA 1, and that these cells in MRL/1 mice may respond poorly to antigens association with either MHA 2 or MHA 1 in the $\mathrm{H}-2$ region which are found in the murine MHC (major histocompatibility complex) on chromosome 17.

One of the regulatory factors of dental caries might be immune function in response to the causative agent, which might be related to $\mathrm{H}-2$ region on chromosome 17 in mice. In fact, salivary IgA against $S$. mutans in MRL/l mice was significantly lower $(\mathrm{p}<0.05)$ than that in MRL/n mice at $130 \mathrm{~d}$ of age after infection with $S$. mutans on d 75. At over $8 \mathrm{w}$ of age, the immune response to antigens associated with MHA 1 or MHA 2 might decline, despite the high serum immunoglobulin levels in MRL/l mice.

Taken together with the results of our previous study ${ }^{[12]}$, we conclude that salivary IgA does not work to prevent caries development after dental caries initiation in MRL/l mice, although salivary IgA against $S$. mutans is one of the important factors regulating the occurrence of dental caries.

\section{Conclusions}

Differences between effects on the salivary immune response to caries occurrence and caries development were demonstrated using MRL/l mice with autoimmune disease and MRL/n mice as controls.

From our previous study and this experiment, we conclude that salivary IgA dose not work to regulate dental caries development, and that salivary $\operatorname{IgA}$ is one of the most important factors regulating the occurrence of dental caries.

\section{References}

[ 1 ] Michalek, S.M. and McGhee, J.R.: Virulence of Streptococcus mutans. An antibiotic-suppressed rat model for studies of pathogenesis, J. Dent. Res., 56, 205-211, 1977

[2 ] Ooshima, T., Sobue, S., Hamada, S. and Kotani, S.: Susceptibility of rats, hamsters and mice to carious infection by Streptococcus mutans serotype c and d organisms, J. Dent. Res., 60, 855-859, 1981

[ 3 ] Kurihara, Y., Naito, T., Obayashi, K., Hirasawa, M., Kurihara, Y. and Moriwaki, K: Caries susceptibility in inbred mouse strains and inheritance patterns in F1 and backcross (N2) progeny from strains with high and low caries susceptibility, Caries Res., 25, 341-346, 1991

[ 4 ] Arnold, R.R., Cole, M.F., Prince, S. and McGhee, J.R.: Secretory IgM antibodies to Streptococcus mutans in subjects with selective IgA deficiency, Clin. Immunol. Immunopathol., 8, 475-486, 1977

[ 5 ] Evans, R.T., Emmings, F.G. and Genco, R.J.: Prevention of Streptococcus mutans infection of tooth surfaces by salivary antibody in irus monkeys (Macaca fascicularis ), Infect. Immun., 12, 293-302, 1975

[6] Gregory, R.L., Michalek, S.M., Filler, S.J., Mestecky, J. and McGhee, J.R.: Prevention of Streptococcus mutans colonization by salivary IgA antibodies, J. Clin. Immunol., 5, 55-62, 1985

[ 7 ] Krasse, B., Emilson, C.G. and Gahnberg, L.: An anticaries vaccine: Report on the status of research, Caries Res., 21, 255-276, 1987

[ 8 ] Murphy, E.D. and Roths, J.B.: Autoimmunity and lymphoproliferation induction by mutant gene lpr, and acceleration by a male-associated factor in strain BXSB mice. In Genetic Control of Autoimmune Disease, N. L. Warner, ed., Elsevier North Holland, New York, 207-221, 1978

[9] Lewis, D.E., Giorgi, J.V. and Warner, N.L.: Flow cytometry analysis of T cells and continuous T-cell lines from autoimmune MRL/1 mice, Nature, 289, 298-300, 1981

[10] Prud'homme, G.J., Park, C.L., Fiser, T.M., Kofler, R., Dixon, F.J. and Theofilopoulus, A.N.: Identification of a B cell differentiation factor(s) spontaneously produced by proliferating $\mathrm{T}$ cells in murine lupus strains of the lpr/lpr genotype, J. Exp. Med., 157, 730-742, 1983.

[11] Prud'homme, G.J., Balderas, R.S., Dixon, F.J. and Theofilopoulos, A.N.: B cell dependence on and 
response to accessory signals in murine lupus strains, J. Exp. Med., 157, 1815-1827, 1983

[12] Maeda, T., Shima, M. and Kurihara, Y.: Relationship between serum and salivary immunoglobulin levels and dental caries in mice with autoimmune disease - Inoculating S. mutans at preoccurrence of the disease, Pediatric Dent. J., 4(1), 29-35, 1994

[13] Keyes, P.H.: Dental caries in the molar teeth of rats-2, J. Dent. Res., 37, 1088-1099, 1958

[14] Williams, R.C. and Gibbons, R.J.: Inhibition of bacterial adherence by secretory immunoglobulin A: a mechanism of antigen disposal, Science, 117, 697-699, 1972

[15] McGhee, J.R., Michalek, S.M., Webb, J., Navia, J.M., Rahman, A.F. and Legler, D.W.: Effective immunity to dental caries: protection of gnotobiotic rats by local immunization with Streptococcus mutans, J. Immunol., 114, 300-305, 1975

[16] Michalek, S.M., McGhee, J.R., Mestecky, J., Arnold, R.R. and Bozzo, L.: Ingestion of Streptococcus mutans induces secretory immunoglobulin A and caries immunity, Science, 192, 1238-1240, 1976

[17] Taubman, M.A. and Smith, D.J.: Effects of local immunization with glucosyltransferase fractions from Streptococcus mutans on dental caries in rats and hamsters, J. Immunol., 118, 710-716, 1976

[18] Challacombe, S.J., Guggenheim, B. and Lehner, T.: Serum and salivary antibodies to glucosyltransferase in dental caries, Nature, 238, 219, 1972

[19] Challacombe, S.J.: Serum and salivary antibodies to Streptococcus mutans in relation to the development and treatment of human dental caries, Arch. Oral Biol., 25, 495-502, 1980

[20] Mestecky, J., McGhee, J.R., Arnold, R.R., Michalek, S.M., Prince, S.J. and Babb, J.L.: Selective induction of an immune response in human external secretions by ingestion of bacterial antigen, $J$. Clin. Invest., 61, 731-737, 1978

[21] Gregory, R.L., Sholler, M., Filler, S.J., Crago, S.S., Prince, S.J., Allansmith, M.R., Micholek, S.M., Mestecky, J. and McGhee, J.R.: IgA antibodies to oral ocular bacteria in human external secretions, Protides Biol. Fluids Proc. Colloq., 32, 53-56, 1985

[22] Gregory, R.L., Filler, S.J., Michalek, S.M. and McGhee, J.R.: Salivary immunoglobulin A and serum antibodies to Streptococcus mutans ribosomal preparations in dental caries-free and caries-susceptible human subjects, Infect. Immun., 51, 348-351, 1986

[23] Lehner, T., Lamb, J.R., Welsh, K.L. and Batchelor, R.J.: Association between HLA-DR antigens and helper cell activity in the control of dental caries, Nature, 292, 770-772, 1981

[24] Niiyama, T., Kojima, H., Mizuno, K., Matsuno, Y., Fuji, H., Misonou, J., Natori, T., Aizawa, M. and Oikawa, K.: Genetic control of the immune responsiveness to Streptococcus mutans by the major histocompatibility complex of the rat (RT1), Infect. Immun., 55, 3137-3141, 1987

[25] Andrews, B.S., Eisenberg, R.A., Theofilopoulos, A.N., Izui, S., Wilson, C.B., McConahey, P.J., Murphy, E.D., Roths, J.B. and Dixon, F.J.: Spontaneous murine lupus-like syndromes, J. Exp. Med., 148, 1198-1215, 1978

[26] Lehner, T., Harty, W. and Doubleday, B.: Antibodies to a streptococcal antigen in gingival capillary and crevicular fluid washing, collected from man and non-human primates, Arch. Oral. Biol., 32, 117122,1987

[27] Wofsy, D., Hardy, R.R. and Seaman, W.E.: The proliferating cells in autoimmune MRL/l mice lack L3T4, and antigen on "Helper" T cells that is involved in the response to class 2 major histocompatibility antigens, J. Immunol., 132, 2686-2689, 1984 
Table 1 Caries scores at $130 \mathrm{~d}$ of age in mice inoculated with $S$. mutans on 75

\begin{tabular}{lll}
\hline Strains & $\mathrm{n}$ & Mean \pm S.E. \\
\hline MRL/1 & 10 & $230.8 \pm 15.6$ \\
MRL/n & 10 & $31.6 \pm 11.9$
\end{tabular}

$$
* *: \mathrm{p}<0.01
$$

Table 2 Salivary IgA levels against $S$. mutans at $130 \mathrm{~d}$ of age in mice inoculated with $S$. mutans on d 75

\begin{tabular}{ccc}
\hline Strains & $\mathrm{n}$ & Mean \pm S.E. $\left(\times 10^{-5} \mathrm{mg} / \mathrm{ml}\right)$ \\
\hline MRL/1 & 10 & $1.08 \pm 0.95 \checkmark *$ \\
MRL/n & 10 & $2.58 \pm 1.30 *$ \\
\hline
\end{tabular}

$$
*: \mathrm{p}<0.05
$$

